\title{
ERRATUM
}

\section{ERRATUM: A PROCESS TOWARDS SOCIETAL VALUE WITHIN \\ A COMMUNITY-BASED REGIONAL DEVELOPMENT PROJECT}

DOI: 10.12776/QIP.V17I1.180

ANNA ÅSLUND, INGELA BÄCKSTRÖM

Authors would like to correct their article:

Anna Aslund \& Ingela Bäckström, 20012. A process towards societal value within a community-based regional development project. Quality Innovation Prosperity, Vol. 16 No. 2, pp. 71-83.

Sub-chaper 5.5 Verifying of the process maphe support processes - "support for creation of societal value" should be change to the 5.5 Verifying of the process map. 